\title{
Financial Technology 3.0 Adoption in Financial and Non-Financial Institutions from Modified UTAUT Perspective
}

\author{
Valentina Tohang ${ }^{1, *}$ Erika Lo $^{2}$ Adilla Anggraeni ${ }^{3}$
}

\author{
1,2,3 Bina Nusantara University \\ *Corresponding author. Email: vtohang@binus.edu,
}

\begin{abstract}
In the financial industry, the innovations of financial technology (FinTech) is vital to provide convenience to the public to access financial products and transaction facilities. Nevertheless, FinTech is recently growing in the non-financial industry and has been able to improve financial inclusion in a wider area. There are several FinTech services such as payment, lending, financing, financial planning, and investment. The objective of this research is to examine the behavior of the user towards the acceptance of technology of FinTech 3.0, specifically payment services, in the financial and non-financial industry based on the modified Unified Theory of Acceptance and use of Technology Model (UTAUT). The research outcome illustrates that the user acceptance in financial technology for non-financial institutions has a significant effect of all variables towards behavior intention except for system quality. While for financial institutions service quality are the variables that does not have a significant affect towards behavior intention. This research uses a quantitative approach. Two types of questionnaire were distributed to Go Pay (Non-Financial) and Jenius (Financial) institutions users with a target of 100 respondents
\end{abstract}

Keywords: customer adoption, financial technology, financial institutions, non-financial institutions, UTAUT

\section{INTRODUCTION}

The rise of digital technology enables people to work or live in a more effective and efficient way. Beside of fulfilling human's satisfaction, digital technology also can be the bridge for businesses to have innovations, resulting in better company's performance. Businesses start thinking about how to change their business model because nowadays the landscape of the business is highly affected by the transformation of digital technology. Financial technology is widely used in both financial and non-financial services industry.

The financial technology (FinTech) product is varied from payments, insurance, deposit and lending, capital raising, investment management and market provisioning [1]. This product under FinTech can be used by financial and non-financial industry according to their business sector. For example; Banking (financial industry) will be using the payment product of financial technology as their main technology product where they provide payment services towards customers. In this research, the authors investigate the customers' intention in using Go Pay as a FinTech product from the non-financial institution and Jenius as a financial institution's product. Despite the growth of financial technology and its usage, very few research has been conducted to further examine and compare the factors that may influence customers' adoption of FinTech. The aim of this study is to find out factors that drive customer intention to adopt financial technologies.

\section{LITERATURE REVIEW}

\subsection{Financial Technology 3.0}

Financial technology can be seen from two different perspectives, first as a segment of the start-up world. Second as a technology that used to support financial services, from payment methods, funds transfer, loans, fundraising, to asset management [2]. It has been transforming for the past years, commencing from financial technology 1.0 to 2.0 and into 3.0, in Indonesia. The financial technology 3.0 generation is supported by the technology of smartphone, or in advance level supported by artificial intelligence (AI) and internet of things (IoT) which enable the systems to assist the verification process and safeguard transaction risk timely and efficiently. With the growth of financial services in Indonesia, the technology also moving towards innovative 
services, which involved non-financial industries to compete with the financial institutions [3]. This circumstances lead to a more open competition between both industries. Go-Pay by GoJek and Jenius as one prominent product of Bank BTPN are the examples of payment technology in non- financial and financial industry, respectively. These two payment technology has been used widely with almost similar aims to assist people in managing their payment activities easily, smartly and safely by using android and iOS-based smartphones.

\subsection{Unified Theory of Acceptance and Use of Technology (UTAUT model)}

The UTAUT model was initiated from the development of the Technology Acceptance Model (TAM), which is used to testing the user acceptance of an information system [4]. He initial model has been long developed and currently used widely and well known with the UTAUT. This model consists of several variables; the first variable is performance expectancy which shows the extent to which a person believes that using the system will help him or she achieve a performance advantage in the job.

The second variable, effort expectancy is defined as the level of convenience associated with system usage. Venkatesh, et al. [5] also found that effort expectancy had an effect on behavioral intention. Instead, Dasgupta, et al. [6] finds that effort expectancy does not affect behavioral intention.

Social influences are defined as the extent to which an individual feels it is important that others believe he or she should use the new system. It is reported that social influence affects behavioral intention.

Facilitating conditions are defined as the extent to which a person believes that the existing organizational and technical infrastructure supports the use of the system. The facilitating conditions have no effect on behavioral intention, but it affects the use of behavior. This is shown in the developed UTAUT model that facilitating condition only affect the use of behaviour [5]

Behavioral intention can be defined as a measure of strength of one's intentions to perform certain behaviors [5]. In the basic concept of user acceptance model that has been developed, behavioral intention becomes the intermediate variables of user reaction relationships over the use of information technology with actual use (use behavior). The role of behavioral intention as predictor use behavior has been widely accepted in various user acceptance models [5] and [6]

\section{HYPOTHESIS DEVELOPMENT}

Kang [7] Research of mobile application using UTAUT model shows that performance expectancy does not have a significant influence towards behavioural intention when it comes to measuring the use of mobile apps. Martins, et al.
[8] conducted a research using UTAUT model to measure the user adoption of internet banking; their finding shows a significant relationship between performance expectancy and behavioural intention. Therefore, it can be hypothesized that:

H1: Performance Expectancy (PE) will have a positive influence on behavioral intention to use financial technology 3.0 .

Venkatesh, et al. [5] found that effort expectancy had an effect on behavioral intention. Wang and Wang [9] also shows that there is a positive relation between effort expectancy with behavioural intention. Thus, it can be hypothesized that:

H2: Effort Expectancy (EE) will have a positive influence on behavioral intention to use financial technology 3.0.

The UTAUT model also underlines that the influence from our surroundings might also affect the behavioural intention. Social influences are defined as the extent to which an individual feels it is important that others believe he or she should use the new system. The findings by Venkatesh et al says that social influence has an effect on behavioural intention [5]. Chong, et al. [10], explained that social influences do not have a significant impact towards behavioural intention in the adoption of mobile technology. Therefore, it can be hypothesized that:

H3: Social Influence will have a positive influence on behavioral intention to use financial technology 3.0.

According to McGill, et al. [11], the existing system quality in the IS Success model of DeLone and McLean contains two elements, subjective and objective. The measures used by Delone and McLean to measure system quality are ease of use, functionality, reliability, flexibility, data quality, the possibilities, integration, and importance.

Seddon and Kiew [12] tested the effect of system quality variables on user satisfaction. The results are consistent with Delone and McLean test results [12]. Other researchers who tested the relationship between these two variables were [13]. Roldán and Millán [13] Support the relationship between these two variables. Khan, et al. [14] showed that service quality in the banking sector has a significant effect towards customer satisfaction as well as customer loyalty.

[8] Use the UTAUT model to understand the internet banking adoption in financial institutions. They used a modified UTAUT model as well, where UTAUT combined with the perceived risk factor. Considering the importance of service and system quality in banking sector in determining customer satisfaction, the researchers incorporate service quality and system quality to measure user satisfaction as their dependent variable in measuring user acceptance. Since then, it comes the following hypotheses:

H4: Service Quality (SerQ) will positively influence the behavior intention in using financial technology 3.0. 
H5: System Quality (SysQ) will positively influence the behavior intention in using financial technology 3.0.

According to Martins, et al. [8], behavioural intention and use behaviour shows a positive relationship while study of Pynoo, et al. [15] in a digital learning environment shows a negative relationship. Additionally, Forsgren, et al. [16] findings show that behavioural intention does not have a positive impact towards user satisfaction while [4] findings have shown the opposite.

However, it is hypothesized that:

H6: Behavioural Intention (BI) will positively influence user behavior in using financial technology 3.0.

H7: Behavioural Intention (BI) will positively influence user satisfaction in using financial technology 3.0.

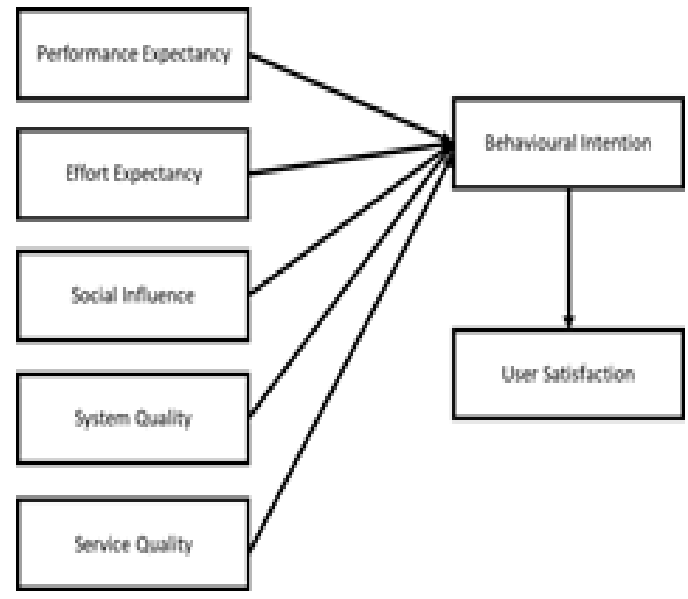

Figure 1 The Modified UTAUT Model

\section{METHODS}

The study utilizes quantitative approach. Survey method was employed as a data collection method. Initially, we have received 158 respondents, in which 153 have been considered as valid respondents that participated in the research. Five questionnaire were eliminated since respondents did not have any experiences with the mentioned FinTech platform. The distribution of the survey questionnaire was done through social media applications (WhatsApp, Line).

The questionnaire was adopted from the previous study of Venkatesh, et al. [17] and adjusted based on the objective of this research. The researchers have also conducted a pre-test study before distributing the questionnaires for the actual research. The data was further analysed using partial least square method.

\subsection{Validity and Reliability}

The validity test is conducted to test whether the survey questionnaire data collected is valid or not. In this research, the author is going to use construct validity. Construct validity is commonly used for instruments intended to measure concept variables, both of which are typical performance such as instruments for measuring attitudes, interests, self-concept, locus control, leadership style, achievement motivation, etc. [18]. The test of construct validity will be evaluated through convergent and discriminant validity test.

Convergent validity is the degree of correlation between different measurement instruments used to measure the same construct. For testing the convergent validity, Confirmatory Factor Analysis (CFA) will be used. Confirmatory Factor Analysis is known as Structural Equation Modelling (SEM) analysis. It is to estimate the factor loadings or standardize loadings which the validity value is higher or equal to 0.5 [19]. While discriminant validity is a measure of how far a measure is different from other doses that can be compared with. It usually will be created when there is no correlation between two variables [18]. According to Hair, et al. [19], Average Variance Extracted (AVE) is used to test discriminant validity.

Reliability test is a tool used to measure how reliable indicators of variables or constructs [20]. An indicator is considered to be reliable if one's response to a statement is consistent or stable from time to time. In this research, Cronbach's Alpha, Composite reliability and Average Variance Extracted (AVE) will be used in order to measure the reliability of the model.

Cronbach Alpha's is a reliability coefficient that shows how well the item are positively correlated with one another. [19] stated that Cronbach's alpha value that is above 0.7 is considered to be reliable. While for composite reliability, the reliable value is between the range of 0.7 to 0.9 and for Average Variance Extracted (AVE) above 0.50 or $50 \%$ is considered to be reliable [19]. All of the measurements in the study have met the reliability, convergent and discriminant validity based on the above criteria.

\section{RESULTS AND DISCUSSIONS}

In total, there are 92 respondents for Go Pay and 61 respondents for Jenius. 
Table 1. Outer Loading Matrix : GoPay

\begin{tabular}{|c|c|c|c|c|c|c|c|c|}
\hline & PE & EE & SI & SERQ & SYSQ & $\mathrm{BI}$ & US & UB \\
\hline PE1 & $-0,652$ & & & & & & & \\
\hline PE2 & $-0,459$ & & & & & & & \\
\hline PE3 & 0,849 & & & & & & & \\
\hline PE4 & 0,705 & & & & & & & \\
\hline PE5 & 0,782 & & & & & & & \\
\hline EE1 & & 0,838 & & & & & & \\
\hline EE2 & & 0,855 & & & & & & \\
\hline EE3 & & 0,755 & & & & & & \\
\hline EE4 & & $-0,028$ & & & & & & \\
\hline EE5 & & 0,81 & & & & & & \\
\hline $\mathrm{SI} 1$ & & & 0,795 & & & & & \\
\hline $\mathrm{S} 12$ & & & 0,888 & & & & & \\
\hline $\mathrm{SI3}$ & & & $-0,013$ & & & & & \\
\hline $\mathrm{S} 14$ & & & $-0,090$ & & & & & \\
\hline SI5 & & & 0,843 & & & & & \\
\hline SERQ1 & & & & 0,754 & & & & \\
\hline SERQ2 & & & & 0,958 & & & & \\
\hline SERQ3 & & & & 0,929 & & & & \\
\hline SERQ4 & & & & $-0,142$ & & & & \\
\hline SERQ5 & & & & 0,766 & & & & \\
\hline SYSQ1 & & & & & $-0,095$ & & & \\
\hline SYSQ2 & & & & & 0,532 & & & \\
\hline SYSQ3 & & & & & $-0,353$ & & & \\
\hline SYSQ4 & & & & & 0,857 & & & \\
\hline $\mathrm{Bl}$ & & & & & & 0,825 & & \\
\hline $\mathrm{Bl} 2$ & & & & & & 0,767 & & \\
\hline $\mathrm{BI3}$ & & & & & & $-0,554$ & & \\
\hline $\mathrm{B} 14$ & & & & & & 0,765 & & \\
\hline US1 & & & & & & & 1 & \\
\hline UB1 & & & & & & & & 1 \\
\hline
\end{tabular}

Table 2. Outer Loading Matrix : Jenius

\begin{tabular}{|l|r|r|l|l|l|l|l|l|}
\hline & PE & EE & SI & SERQ & SYSQ & BI & US & UB \\
\hline PE1 & 0,905 & & & & & & & \\
\hline PE2 & $-0,060$ & & & & & & & \\
\hline PE3 & $-0,158$ & & & & & & & \\
\hline PE4 & 0,936 & & & & & & & \\
\hline EE1 & & 0,810 & & & & & & \\
\hline EE2 & & 0,825 & & & & & & \\
\hline EE3 & & $-0,738$ & & & & & & \\
\hline EE4 & & & & & & & & \\
\hline
\end{tabular}




\begin{tabular}{|c|c|c|c|c|c|c|c|c|}
\hline & PE & $\mathrm{EE}$ & SI & SERQ & SYSQ & $\mathrm{BI}$ & US & UB \\
\hline SI1 & & & $-0,612$ & & & & & \\
\hline $\mathrm{SI} 2$ & & & $-0,099$ & & & & & \\
\hline $\mathrm{SI} 3$ & & & $-0,033$ & & & & & \\
\hline SI4 & & & 0,792 & & & & & \\
\hline SERQ1 & & & & 0,868 & & & & \\
\hline SERQ2 & & & & $-0,574$ & & & & \\
\hline SERQ3 & & & & 0,951 & & & & \\
\hline SYSQ1 & & & & & $-0,082$ & & & \\
\hline SYSQ2 & & & & & 0,719 & & & \\
\hline SYSQ3 & & & & & 0,903 & & & \\
\hline Bl1 & & & & & & 0,867 & & \\
\hline BI2 & & & & & & $-0,405$ & & \\
\hline $\mathrm{B} 13$ & & & & & & 0,870 & & \\
\hline BI4 & & & & & & 0,751 & & \\
\hline US1 & & & & & & & 1 & \\
\hline UB1 & & & & & & & & 1 \\
\hline
\end{tabular}

Inner model or structural model testing is conducted to see the relationship between construct, significance value and R-square of the research model. The structural model is evaluated by using R-square Adjusted for the $t$ test dependent construct as well as the significance of the structural path parameter coefficients

Table 3. Adjusted R-Square of GoPay and Jenius

\begin{tabular}{|l|c|c|}
\hline \multicolumn{1}{|c|}{ Variable } & GoPay & Jenius \\
\hline Behavioral Intention & Adjusted R-square & Adjusted R-square \\
\hline Use Behavior & 0,410 & 0,741 \\
\hline Use Satisfaction & 0,166 & 0,245 \\
\hline
\end{tabular}

The significance of estimated parameters provides very useful information on the relationship between research variables. Test results with bootstrapping provided as follows.

Table 4. Hypotheses Testing Summary

\begin{tabular}{|c|c|c|c|c|c|c|}
\hline & \multicolumn{4}{|c|}{ GoPay } & \multicolumn{2}{c|}{ Jenius } \\
\cline { 2 - 7 } & t stat & $\mathrm{p}$-value & Result & $\mathrm{t}$ stat & $\mathrm{p}$-value & Result \\
\hline H1 & 1,996 & 0,018 & Supported & 3,208 & 0,001 & Supported \\
\hline H2 & 2,805 & 0,009 & Supported & 1,979 & 0,039 & Supported \\
\hline H3 & 0,87 & 0,385 & Not Supported & 0,626 & 0,531 & Not Supported \\
\hline H4 & 2,553 & 0,011 & Supported & 1,172 & 0,242 & Not Supported \\
\hline H5 & 1,365 & 0,173 & Not Supported & 1,976 & 0,032 & Supported \\
\hline H6 & 5,163 & 0,000 & Supported & 4,96 & 0,000 & Supported \\
\hline H7 & 5,397 & 0,000 & Supported & 5,887 & 0,000 & Supported \\
\hline
\end{tabular}

The above table compared results from the 2 (two) different providers of financial and non-financial institution. Service Quality and System Quality have shown mixed result. Service Quality is considered significant in a nonfinancial institution compared to the financial institution while system quality works vice versa. These results might 
be due to the customers' convenience on customer services provided by Go Pay, in terms of quick response to complaints as well as good promotional or deals offered. On the other hand, system quality considered critical in financial institution since customers believe that problems or errors should not be issues to the financial institution products/services.

\section{CONCLUSION}

FinTech offers financial solutions that are not only dominated by financial institutions. Findings of this research show that there are three variables that influence how customers use GoPay and Jenius application: (1) performance expectancy, where users find it helpful that they can control their money or make transaction without going to the banks. (2) Effort expectancy has a significant influence towards behavioural intention. This suggests that when the customers receive clear guidance on using the application, it is not hard for them to form intention to use both Go Pay and Jenius application (3) system quality of Jenius application influences customer intention in using the apps, while service quality is significant to the non-financial institutions.

\section{ACKNOWLEDGMENT}

The authors would like to thank all the respondents participated in the study.

\section{REFERENCES}

[1] Deloitte Center for Financial Services, Disaggregating Fintech Brighter Shades of Disruption, 2017.

[2] A. Mackenzie, The fintech revolution, London Business School, vol. 26(3), 2015, pp. 50-53.

[3] Maikel Jefriando, Baru 21,8\% Orang RI Dapat Akses Jasa Keuangan, Jokowi Kumpulkan Menteri, BI, dan OJK, Detik Finance, 26-Apr-2016.

[4] F. D. Davis, Perceived usefulness, perceived ease of use, and user acceptance of information technology, MIS quarterly, 1989, pp. 319-340.

[5] V. Venkatesh, M. G. Morris, G. B. Davis, and F. D. Davis, User acceptance of information technology: Toward a unified view, MIS quarterly, 2003, pp. 425478.

[6] S. Dasgupta, M. Haddad, P. Weiss, and E. Bermudez, User acceptance of case tools in system analysis and design: an empirical study, Journal of Informatics Education Research, vol. 9(1), 2007, pp. 51-78.

[7] S. Kang, Factors influencing intention of mobile application use, International Journal of Mobile Communications, vol. 12(4), 2014, pp. 360-379.

[8] C. Martins, T. Oliveira, and A. Popovič, Understanding the Internet banking adoption: A unified theory of acceptance and use of technology and perceived risk application, International Journal of Information Management, vol. 34(1), 2014, pp. 1-13.

[9] H. Y. Wang and S. H. Wang, User acceptance of mobile internet based on the unified theory of acceptance and use of technology: Investigating the determinants and gender differences, Social Behavior and Personality: an international journal, vol. 38(3), 2010, pp. 415-426.

[10] A. Y.-L. Chong, N. Darmawan, K.-B. Ooi, and B. Lin, Adoption of $3 \mathrm{G}$ services among Malaysian consumers: an empirical analysis, International Journal of Mobile Communications, vol. 8(2), 2010, pp. 129-149.

[11] T. McGill, V. Hobbs, and J. Klobas, User developed applications and information systems success: A test of DeLone and McLean's model, Information Resources Management Journal (IRMJ), vol. 16(1), 2003, pp. 2445.

[12] P. Seddon and M.-Y. Kiew, A partial test and development of DeLone and McLean's model of IS success, Australasian Journal of Information Systems, vol. 4(1), 1996.

[13] J. L. Roldán and A. L. Millán, Analysis of the information systems success dimensions interdependence: An adaptation of the DeLone \& McLean's model in the Spanish EIS field, in BITWorld 2000, Conference Proceedings, 2000.

[14] I. U. Khan, M. U. Shahzad, and M. A. Hassan, Internet of Things (IoTs): Applications in Home Automation, IJSEAT, vol. 5, 2017, pp. 79-84.

[15] B. Pynoo, P. Devolder, J. Tondeur, J. Van Braak, W. Duyck, and P. Duyck, Predicting secondary school teachers' acceptance and use of a digital learning environment: A cross-sectional study, Computers in Human behavior, vol. 27(1), 2011, pp. 568-575.

[16] N. Forsgren, A. Durcikova, P. F. Clay, and X. Wang, The integrated user satisfaction model: Assessing information quality and system quality as second-order constructs in system administration, Communications of the Association for Information Systems, vol. 38, 2016, pp. 803-839.

[17] V. Venkatesh, J. Y. Thong, and X. Xu, Consumer acceptance and use of information technology: extending the unified theory of acceptance and use of technology, MIS quarterly, vol. 36(1), 2012, pp. 157178.

[18] G. D. Garson, Partial least squares: Regression and structural equation models, Asheboro, NC: Statistical Associates Publishers, 2016.

[19] J. F. Hair, M. Sarstedt, T. M. Pieper, and C. M. Ringle, The use of partial least squares structural equation modeling in strategic management research: a review of past practices and recommendations for future applications, Long range planning, vol. 45(5-6), 2012, pp. 320-340.

[20] I. Ghozali, Analisis Multivariate dengan program SPSS, Semarang: Badan Penerbit Universitas Diponegoro, 2005 . 